\title{
Accumulation of residual energy of an experimental stove after burning
}

\author{
C. Stone, F. Vranay \\ Laboratory of Excellent Research, Faculty of Civil Engineering, Technical University of Kosice \\ Park Komenskeho 10A, 04200 Kosice, Slovakia \\ E-mail: clayton.stone@tuke.sk
}

\author{
R. Drab \\ Faculty of Economics, Technical University of Kosice \\ Nemcovej 32, 04000 Kosice, Slovakia
}

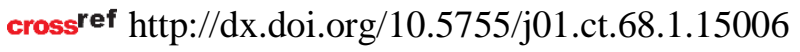

Received 17 May 2016; Accepted 1 March 2017

\begin{abstract}
Engineers, architects and designers increasingly rely on mathematical constructs incorporated into civil engineering programs to explain physical and mechanical phenomena. A low thermal diffusivity represents a material's ability to slow down the rate of heat transfer due to heat absorption and storage, so that high thermal masses are desirable. The thermal inertia of the earth structures in general is an under-researched topic, especially regarding their unique ability to delay and attenuate temperature responses. The paper uses a high temperature difference example, in the form of an experimental stove, to highlight the benefits of a thermal mass. Countries such as Austria, the Czech Republic and Slovakia are known for their ornate historical masonry stoves that grace many stately houses, castles and palaces. They were stoked once or twice daily and radiated heat constantly during the winter months. This guild developed and thrived until the advent of modern HVAC systems in the 20th century. The paper sets out to monitor the temperature difference produced by stoking and firing a simplified experimental stove and analyses the decrease in temperature until it approaches a fixed room temperature. Temperature and heat flux are then observed to determine the total residual heat energy after burning, and the results are discussed in the conclusion. Inspired by these sound principles, based on lessons from the vernacular building traditions that have been used for centuries, the output of this work could be used in future to design an appropriate amount of the thermal mass to maximize thermal efficiency in fireplaces and stoves and as a precedent for a synergetic combination of the thermal mass and renewable energy sources.
\end{abstract}

Key words: volumetric heat capacity, thermal conductivity, heat flux.

\section{Introduction}

A large part of the world's population (more than $40 \%$ ) cook their meals and provide heating for their homes using wood-burning heating stoves, while many of them are from high density materials. Large amounts of heat energy are required to change the temperature of high density materials like rammed earth, making them suitable for fireplaces and stoves where they can function as a thermal battery. Rammed earth was chosen as an eco-friendly, low-tech and vernacular material. The rammed earth stove shown in Fig. 1 was built for commercial purposes as the result of the authors' previous research on rammed earth applicability.

To be effective, a thermal mass should have the capacity to absorb and re-emit close to its full heat storage capacity in a single diurnal cycle [1]. If the conductivity is too low, the passive heating can escape before it is absorbed, but if it is too high, the stored heat is re-released before it is most needed. The rate at which heat is absorbed and released by uninsulated material is referred to as a thermal lag [2]. The amount of useful thermal storage is calculated by multiplying the volumetric heat capacity (VHC) by the total accessible volume of the material, i.e. the volume of material that has its surface exposed to a source of heating or cooling. The VHC of any material is diminished if the material is covered or not in direct contact with its environment. The lag is dependent on thermal conductivity, thickness and temperature difference [3]. The consideration of lag times is important when designing with a thermal mass. 


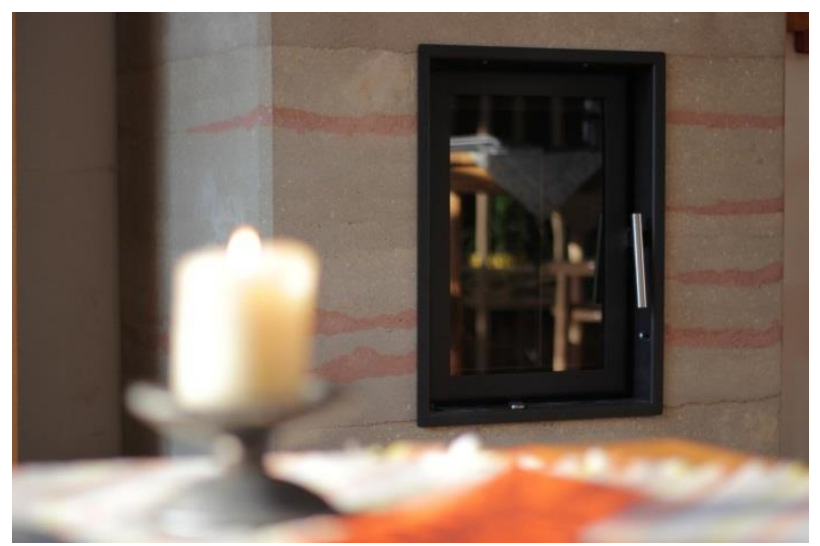

Fig. 1. Luxury rammed earth fireplace prepared by the authors.

\section{Materials and methods}

For the purpose of the experiment, a simplified rammed earth stove was created to determine the total residual heat energy. A stove with known physical and material characteristics was ignited by a fuel with the known energy content (Table 1). The test was performed after 7 days of curing to validate its necessity. The combustion process lasted for approximately 90 minutes. The experiment started post combustion and lasted until the temperature of the stove approached the laboratory air temperature (assumed constant) or until the net heat flow from the heat flux meter dropped to zero.

The stove was prepared in laboratory conditions using a recipe with $8 \%$ of cement content by mass and the optimum moisture content
(OMC) of $10 \%$ [4]. All material components were sieved to remove fractions in excess of $6 \mathrm{~mm}$. The binder consisted of ground silty clays according to [4]. The mixture was rammed into temporary formwork in layers, using a pneumatic tamper. Six air inlet holes with the area of $6000 \mathrm{~mm}^{2}$ were used to supply the stove with oxygen, and an exhaust flue with the diameter of $120 \mathrm{~mm}$ was affixed to $80 \mathrm{~mm}$ of the fire insulation which capped the stove.

The material properties listed in Table 1 were also obtained during previous research done by the authors at the Laboratory of Excellent Research, Civil Engineering Faculty, Technical University of Kosice.

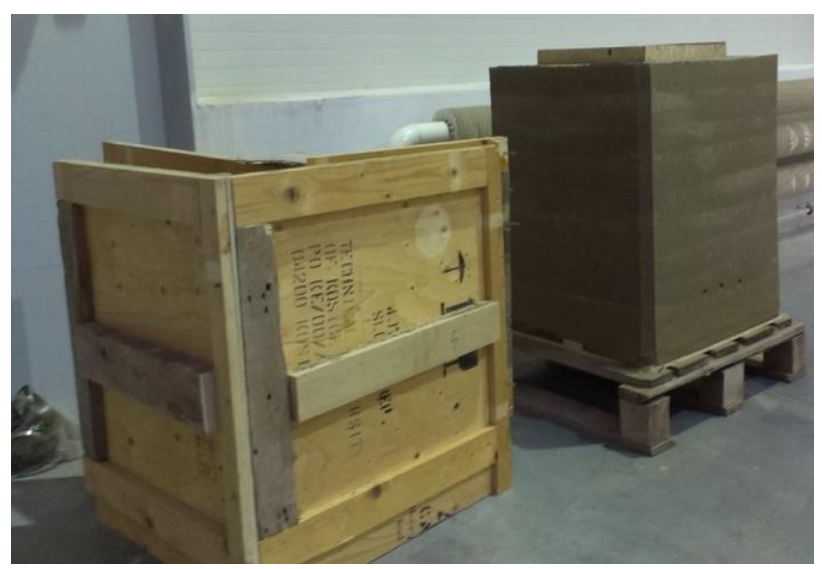

Fig. 2. Removing the formwork of the freshly built stove.

Table 1. Material properties of the stove

\begin{tabular}{|l|c|c|c|}
\hline \multicolumn{1}{|c|}{ Property } & Symbol & Value & Unit \\
\hline Stove dimensions & $L \times W \times H$ & $600 \times 600 \times 800$ & $\mathrm{~mm}$ \\
Earth wall thickness & $d$ & $\sim 140$ & $\mathrm{~mm}$ \\
Radiated area & $A$ & 2.28 & $\mathrm{~m}^{2}$ \\
Density & $\rho$ & 1900 & $\mathrm{~kg} / \mathrm{m}^{3}$ \\
Mass of construction & $m$ & $\sim 400$ & $\mathrm{~kg}$ \\
Thermal conductivity & $\lambda$ & 0.89 & $\mathrm{~W} /(\mathrm{m} \cdot \mathrm{K})$ \\
Heat flux & $Q$ & $0-600$ & $\mathrm{~W} / \mathrm{m}^{2}$ \\
Temperature sensors & $t$ & $18-123$ & ${ }^{\circ} \mathrm{C}$ \\
Specific heat & $C_{p}$ & 850 & $\mathrm{~J} /(\mathrm{kg} \cdot \mathrm{K})$ \\
Input heat 10 kg of sawdust briquettes & $E_{i}$ & $\sim 200$ & $\mathrm{MJ}$ \\
Thermal mass (volumetric heat capacity) & & 1673 & $\mathrm{~kJ} /\left(\mathrm{m}^{3} \cdot \mathrm{K}\right)$ \\
\hline
\end{tabular}


Four nickel chromium thermocouples were attached to the four sides of the stove at approximately one quarter height, four were attached at three quarters height, one was attached at a corner at $50 \%$ of its height and one in a specially made vent at $50 \%$ of the thickness of the material and at $50 \%$ of its height. A heat flux plate was attached at $50 \%$ of the height of the material, and data were logged in the 10-second time intervals on an Ahlborn data acquisition system. A thermographic camera was used for thermal rendering, to detect anomalies and to confirm the significance of the positioning of the sensors.

The residual heat energy in the stove's $0.21 \mathrm{~m}^{3}$ of rammed earth was stored as sensible heat by raising its temperature from $18.7^{\circ} \mathrm{C}$ at the start of the experiment to $76.4{ }^{\circ} \mathrm{C}$. The heat or energy storage can be calculated as:

$$
E=V \cdot \rho \cdot c_{p} \cdot \Delta t=m \cdot c_{p} \cdot \Delta t
$$

where $E$ - sensible heat stored in the material, $\mathrm{J} ; V-$ volume of the substance, $\mathrm{m}^{3} ; \rho$ - density of the substance, $\mathrm{kg} / \mathrm{m}^{3} ; m$ - mass of the substance, $\mathrm{kg} ; c_{\mathrm{p}}-$ specific heat of the substance, $\mathrm{J} /(\mathrm{kg} \cdot \mathrm{K}) ; \Delta T$ temperature change, ${ }^{\circ} \mathrm{C}$.

The net radiation loss rate was derived from the Stefan-Boltzmann Law for black bodies where the radiation energy per time unit from a blackbody is proportional to the fourth power of the absolute temperature and can be expressed by the Stefan-Boltzmann Law [5] as:

$$
q=\sigma \cdot T^{4} \cdot A
$$

where $q$ - the heat transfer per unit time, W; $\sigma-$ the Stefan-Boltzmann constant $\left(\sigma=5.6703 \cdot 10^{-8} \mathrm{~W} /\left(\mathrm{m}^{2} \cdot \mathrm{K}^{4}\right)\right)$; $T$ - absolute temperature, $\mathrm{K} ; A$ - area of the body, $\mathrm{m}^{2}$.

Since the stove is not an ideal black body, a modification of the law was introduced:

$$
q=\varepsilon \cdot \sigma \cdot T^{4} \cdot A
$$

where $\varepsilon$ - the emissivity coefficient of the object $(0<\varepsilon<1)$.

Thus, if a hot object is radiating energy to its cooler surroundings, the net radiation heat loss rate can be expressed as

$$
q=\varepsilon \cdot \sigma \cdot\left(T_{h}^{4}-T_{c}^{4}\right) \cdot A_{c}
$$

where $T_{h}$ - hot body absolute temperature, $\mathrm{K} ; T_{c}-$ cold surroundings absolute temperature, $\mathrm{K} ; A_{c}$ - area of the object, $\mathrm{m}^{2}$.

The emissivity coefficient $\varepsilon$ was determined using a thermographic camera on the actual stove with the average value of 0.91 .

Time lag is an important aspect for stoves as it defines the initial response of the external surface of the body to a heat source. Thermal lags should be short enough to create a change in temperature while the stove is still burning, but long enough to attenuate peak temperatures.

\section{Results and discussion}

The design of the stove was chosen to keep the construction simple and appropriate for experimental purposes and did not adhere to the EN 13229 norm which provides the requirement and limits of pollution emissions to the atmosphere. To avoid the heat conduction, the stove was built on an insulation and sand layer. The stove shape was set as a square for the easier ramming process and formwork limitations. The geometry of the fuel bed was optimised according to suggestions by $[6,7]$, by distributing the cold air flow through six vents and two surface sections. Despite the moisture content and curing time, only the surface of the stove layers had the moisture content below $5 \%$ which could cause heat loss in convection and the physical deterioration of the stove.

The whole experiment can be divided into three main phases:

- the initial phase (from beginning to about $10 \mathrm{~min}$ );

- combustion (from 10 to about $100 \mathrm{~min}$.);

- post-combustion phase (from $100 \mathrm{~min}$. until the end).

\section{Initial phase}

Sawdust briquettes were used as the fuel for the stove. Cylinder-shaped sawdust briquettes with the diameters of $8 \mathrm{~cm}$ and length of $10 \mathrm{~cm}$ were selected, because the briquettes producer stipulated the energy content and because of their repeatability. The ignition was started at several points to assure the homogeneity of the combustion process. 


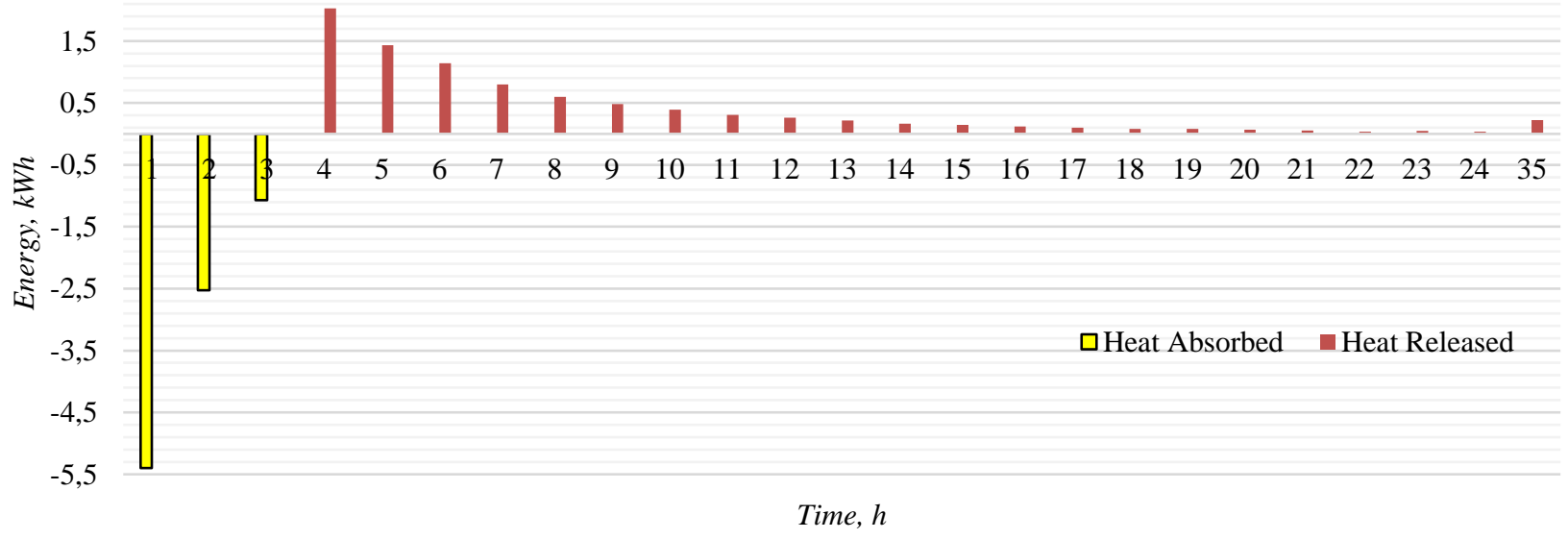

Fig. 3. Residual energy absorbed and released by the stove.

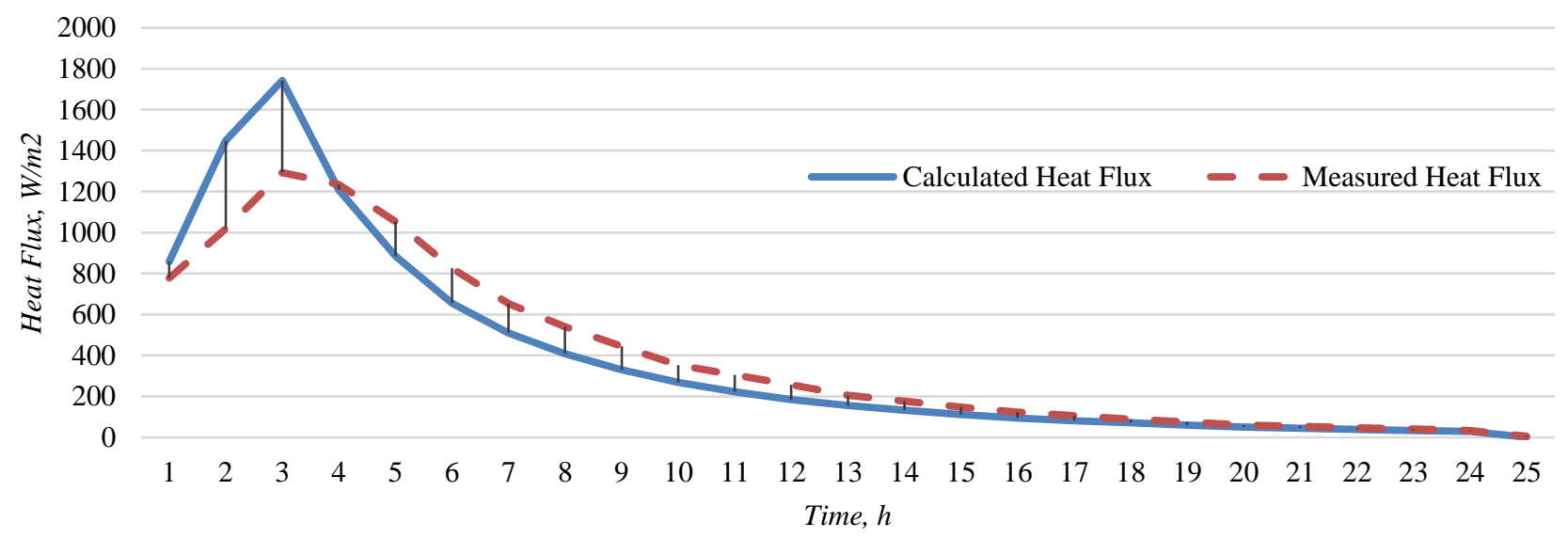

Fig. 4. Correlation between the measured values of the heat flux plate and the values calculated from the net radiance loss rate.

\section{Combustion phase}

The combustion phase lasted for about 90 minutes. In Fig. 3, residual temperatures of the stove recorded an increase for the first three hours, even though the combustion process lasted only for the mentioned 90 minutes. During the phase, approximately $55.56 \mathrm{kWh}$ of energy was released by the combustion process. The temperature was monitored using thermocouples and by means of a data acquisition system. It took the stove $54 \mathrm{~min}$. to exhibit a change in temperature on its outside surface. The maximum temperature reached on the outside surface was $93.8{ }^{\circ} \mathrm{C}$. The maximum temperature at the corners was $64^{\circ} \mathrm{C}$, and in the vent it was $123.4^{\circ} \mathrm{C}$.

\section{Post-combustion phase}

The most significant residual energy was released over the following $8 \mathrm{~h}$; however, since the laboratory was tempered to a constant temperature of $20{ }^{\circ} \mathrm{C}$, it took a total of $35 \mathrm{~h}$ for the external surface to approach the room temperature. Hours 25-35 were summarized as a single entry.
Figure 4 discloses a direct correlation between the measured values of the heat flux plate and the values calculated from the net radiance loss rate, confirming the validity of the modification of the Stefan-Boltzmann's law.

An effective cooling time of $10 \mathrm{~h}$ and $15 \mathrm{~min}$. was the time required for the stove to produce less than $100 \mathrm{~W} / \mathrm{m}^{2}$, and the cool-down temperature of 35 hours was the time it took for the temperature to reach within $1{ }^{\circ} \mathrm{C}$ of the room temperature. As was referenced by [7], the height of the fuel bed, its weight and distribution were also taken into consideration. From this it can be deduced that of the $55.56 \mathrm{kWh}$ net energy produced by burning the sawdust briquettes, a total of $8.99 \mathrm{kWh}$ of the residual storage heat was absorbed and $8.83 \mathrm{kWh}$ was released. The calculated efficiency of the stove was very low, slightly above $16 \%$. The loss during the combustion process was due to heat release through convection, radiation and conduction. On the other hand, the heat storage loss was very low, and almost $98.3 \%$ of the stored energy by the stove was released within the analysed time window. 


\section{Concomitants}

During the end of the combustion phase and in the first two hours of the post-combustion phase, several phenomena emerged. Due to the insufficient curing time of the rammed earth stove, a progressive deterioration in the form of cracks through convection occurred. This effect was recorded as a steam concentration in the combustion chamber corners and in capillary cracks in the material and as the subsequent material deterioration. Visible cracks emerged, where the rammed earth layers connected during the ramming process. Imagery from the thermographic camera (Fig. 5 and Fig. 6) validated the location of the sensors and confirmed the necessity of stipulating adequate curing times evidenced by steam and subsequent cracking.

Figure 5 depicts the contour of the temperature profiles, verifies the position of the sensors and also shows that the temperature at the boundaries of the individual earth layers were not the same. This is a novel observation and, although its effect is trivial, the authors are to date unaware of any documentation reporting the effect. This effect was most pronounced within the first $30 \mathrm{~min}$. of combustion.
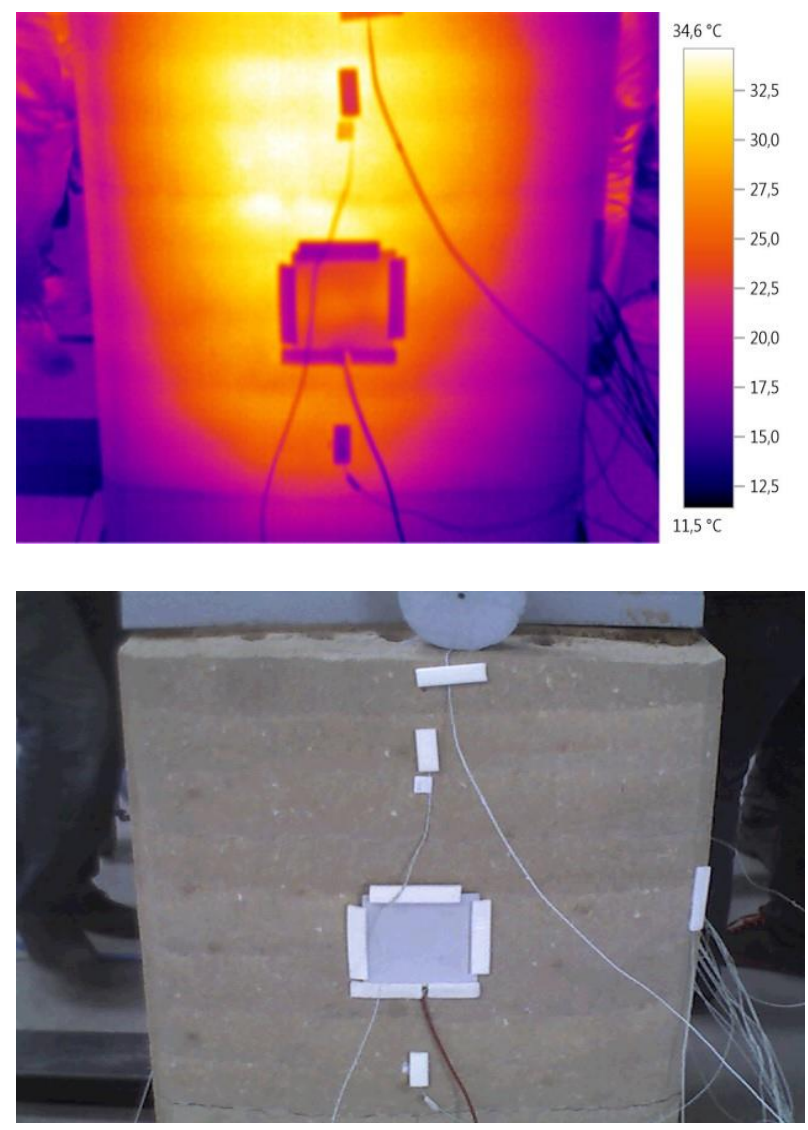

Fig. 5. Validation of sensor placement.
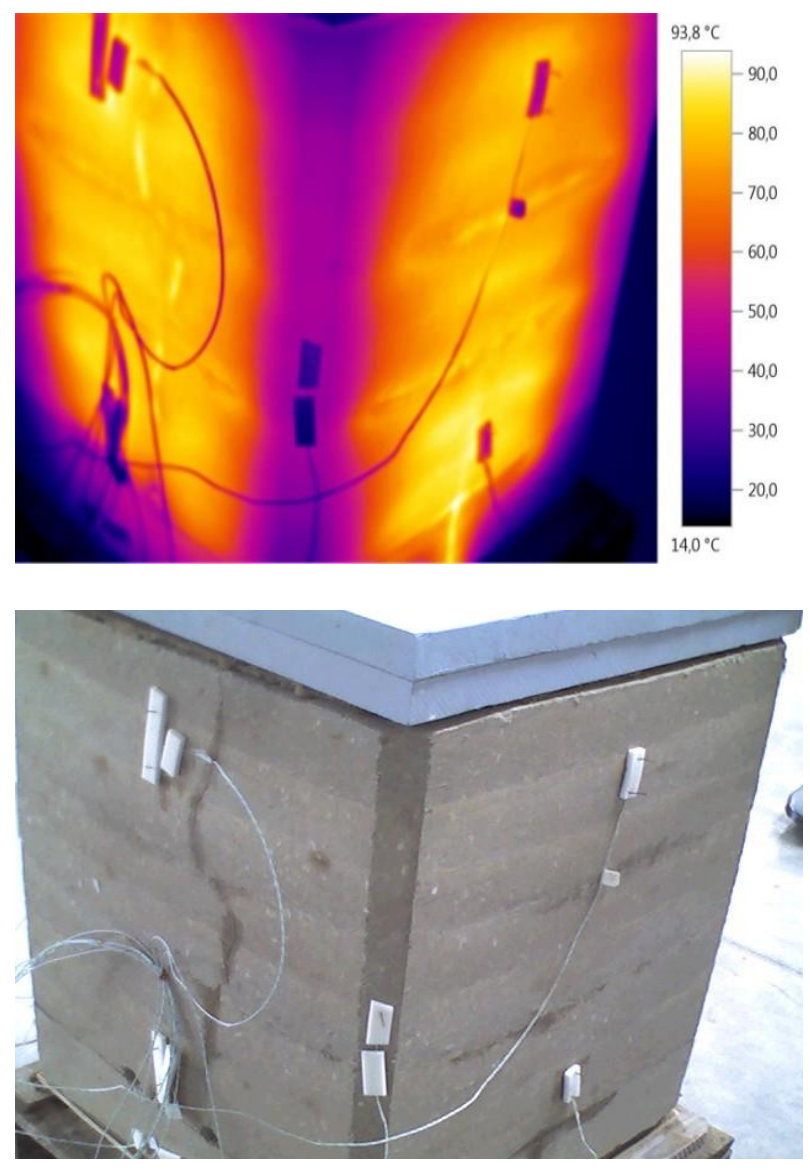

Fig. 6. Above - approaching the maximum surface temperature, below - cracks and steam forming.

Figure 6 illustrates the effects of the insufficient curing time during the most critical time of combustion (approaching the maximum temperature). Very faint hissing sounds of escaping steam were heard, and the palms of our hands dewed almost instantly when held above the fracture. Apart from a vertical cracking, a horizontal delamination was also observed between the first and the second layers of the ramming. This is the slab on which the fuel bed rests and the first rammed wall layer.

\section{Conclusion}

The paper qualifies and quantifies the net residual energy and the applicability of incorporating thermal mass into stoves and fireplaces. The efficiency of stoves can be improved by slowing down the heat flow and increasing the surface exposed to the heat. Inspired by these sound principles, based on lessons from the vernacular building traditions that have been used for centuries, the output of this work could be used in future to design the appropriate amount of thermal mass to maximize thermal efficiency in fireplaces and stoves and as a precedent for a 
synergetic combination of the thermal mass and the renewable energy sources. The further research should be mainly focused on improving the initial and the combustion processes to increase the storage potential. This can be done by slowing the release of burnt gases, using exchangers or various mechanisms and techniques.

\section{Acknowledgements}

This work has been supported by the Slovak Grant Agency for Science (Grant No. 1/0563/15).

\section{References}

1. Korjakins A., Šahmenko G., Būmanis G. Boresilicate glass waste of lamp as a micro-filler for concrete // Construction Science. 2009. Vol. 10. N 10. P. 131-138. http://dx.doi.org/10.2478/v10137-009-0013-1

2. Stone C., Balintova M., Holub M. Feasibility of integrated insulation in Rammed Earth // Materials Science and Engineering. 2015. Vol. 96. N 1. P. 1-7. http://dx.doi.org/10.1088/1757-899X/96/1/012030

3. Reardon C., McGee C., Milne G. Passive design. Thermal mass // Your home technical manual. $4^{\text {th }}$ ed. Department of the environment, water, Heritage and the arts. 2008. P. 114-118.

4. Stone C., Katunsky D. Dynamic thermal properties of uninsulated rammed earth envelopes // Pollack Periodica. 2015. Vol. 10. N 1. P. 103-112. http://dx.doi.org/10.1556/Pollack.2015.10.1.10

5. Eckhardt W. Corrections to the StefanBoltzmann radiation law in cavities with walls of finite conductivity // Optics Communications. 1975. Vol. 14. N 1. P. 95-98.

http://dx.doi.org/10.1016/0030-4018(75)90066-8

6. Sornek K., Filipowicz M., Rzepka K. Study of clean combustion of wood in a stove-fireplace with accumulation // Journal of the Energy Institute. 2016. http://dx.doi.org/10.1016/j.joei.2016.05.001

7. Szubel M., Warszewska M., Basista G., Podlasek S. Impact of the geometry of the fuel bed in the fireplace on the quality of the combustion process // Monographs of Department of Power Systems and Environmental Protection Facilities. Krakow, 2015. P. 127-139.

\section{Stone, F. Vranay, R. Drab \\ EKSPERIMENTINĖS KROSNIES LIKUTINĖS ENERGIJOS KAUPIMAS PO DEGIMO}

\section{S a n tra u k}

Šiame darbe kiekybiškai ịvertinta grynoji likutinė krosnies energija po degimo ir galimybè taikyti terminę masę krosnyse ir židiniuose. Krosnių efektyvumą galima padidinti lètinant šilumos srautą ir didinant karščio veikiamą paviršių. Tyrimo rezultatus galima panaudoti terminès masès tinkamų kiekių paieškai, siekiant kiek ịmanoma daugiau padidinti krosnių ir židinių termini efektyvumą. Tai taip pat būtų terminès masès ir atsinaujinančių energijos išteklių sinerginio derinio precedentas. Tolesnius tyrimus reikètų skirti degimo procesui tobulinti, siekiant padidinti šilumos išlaikymo potencialą. Tai įmanoma pasiekti sulètinus degimo dujų pašalinimą, panaudojus šilumokaičius ar kitus mechanizmus bei metodus.

Reikšminiai žodžiai: savitoji šiluminè talpa, šiluminis laidumas, šilumos srautas. 